\title{
POŚTA
}

TELEKOMUNIKÁCIE A

ELEKTRONICKY OBCHOD

\section{VÝVOJ KOMUNIKÁCIE V ZÁVISLOSTI OD ŽIVOTNÉHO CYKLU PODNIKOVEJ KRÍZY}

\author{
Jaroslava Kádárová*
}

\section{Úvod}

Podnikové krízy nie sú všeobecne vítane a objavia sa zvyčajne neočakávane. Všetky krízy, zavinené alebo nezavinené, náhodné alebo predpovedatel'né, majú jedno spoločné, postavia podnik pred vel'kú výzvu v oblasti informácii a komunikácie.

Životný cyklus podnikovej krízy nezávisí len od druhu a rozsahu krízy, ale jej vývoj je určovaný tým, ako podnik na krízu reaguje a akú uplatňuje internú a externú komunikáciu. Bez ohladu na to, či je kríza zavinená vlastnou činnost'ou podniku alebo externými vplyvmi, či sa jej dalo vyhnút’ za určitých okolností alebo bola minimálne predpovedaná, krízová komunikácia má v každom prípade podstatný význam.

\section{Význam krízovej komunikácie pre podnik}

Každá podniková kríza má životný cyklus, ktorý pozostáva z troch fáz a šiestich krokov.

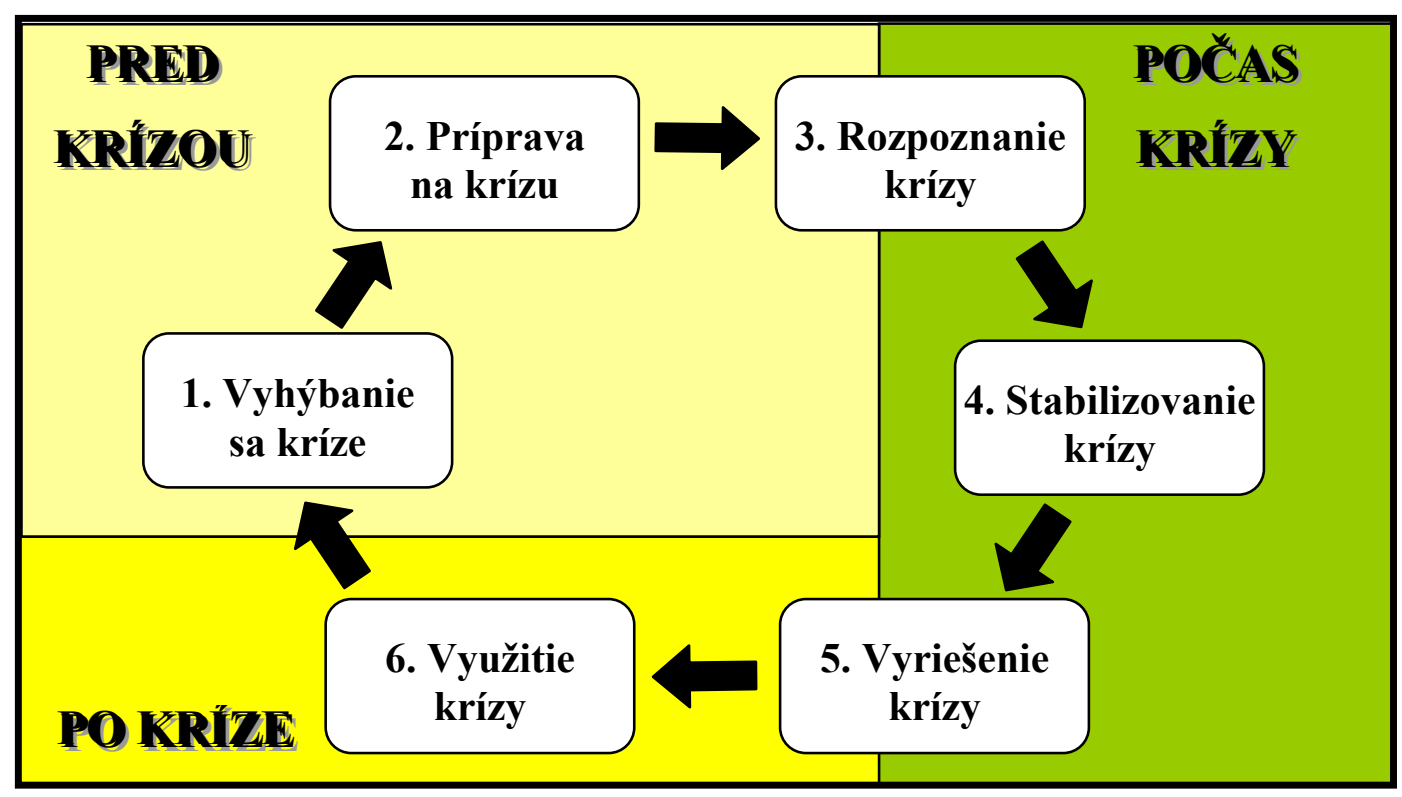

Obr. 1 Životný cyklus podnikovej krízy

\footnotetext{
* Ing. Jaroslava Kádárová, PhD., Technická univerzita v Košiciach, Strojnícka fakulta, Katedra manažmentu a ekonomiky, Němcovej 32, 04200 Košice,

tel.: +421556023231, fax: +421556023233, e-mail: Jaroslava.Vidova@tuke.sk
} 
Samozrejme, že každá kríza má rôznu dížku jednotlivých fáz, čo je možné ovplyvňovat' aj vhodnou komunikáciou a reakciou na vzniknutú situáciu. Intenzitu komunikácie v priebehu podnikovej krízy ovplyvňujú predovšetkým tri faktory:

- rastúce spravodajstvá masovokomunikačných prostriedkov o podnikatel'ských rizikách,

- silný nárast st’ažností a súdnych konaní k jednotlivým výrobkom a činnostiam,

- vplyv krízy na reputáciu podniku a priemysel.

Každá reakcia podniku na vzniknutý krízový jav v podniku má vplyv na zmenu hodnoty podniku. Na obrázku 2 je ilustrovaný vývoj hodnoty podniku pri vhodnej a nevhodnej reakcii.

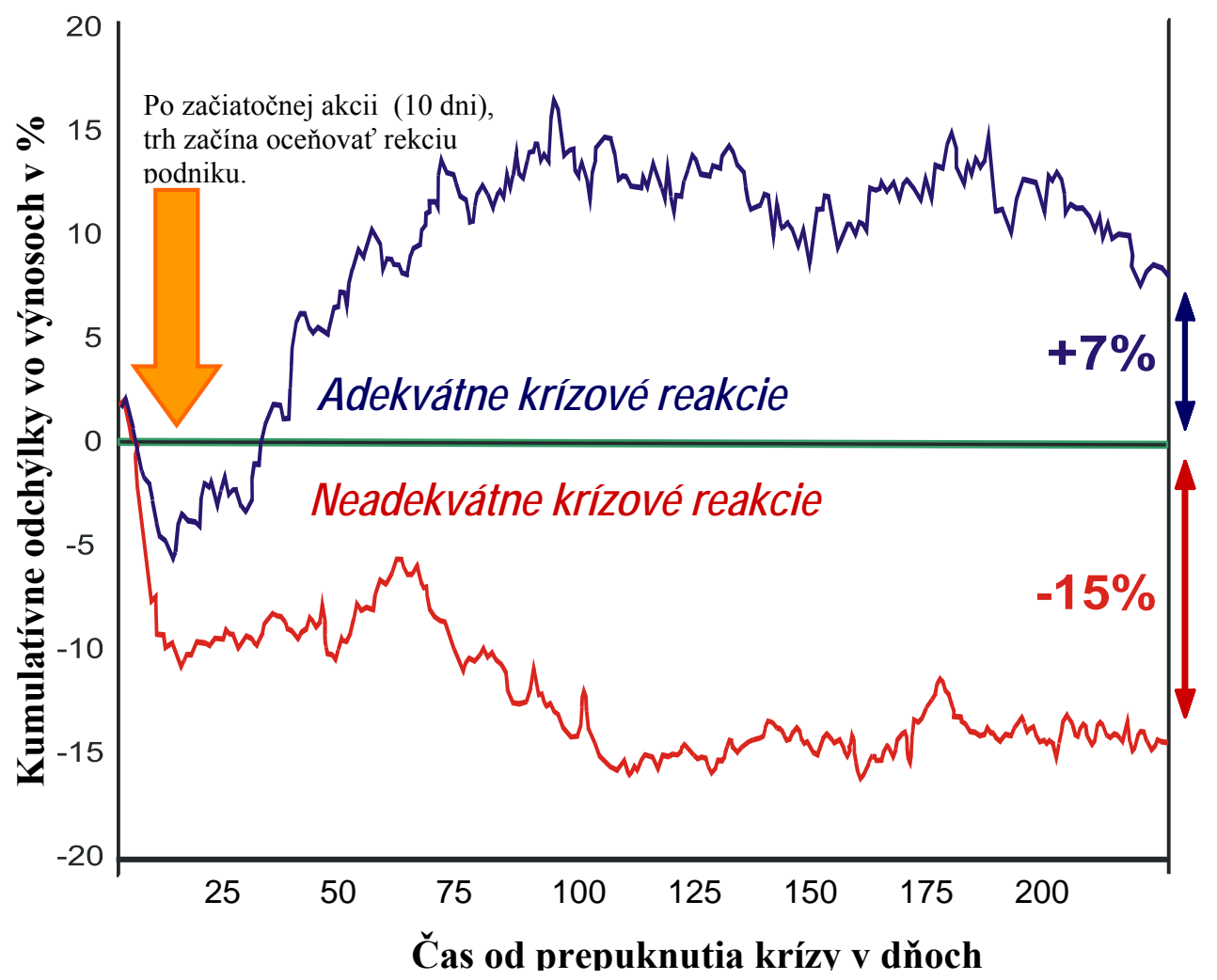

Obr. 2 Vplyv komunikácie na hodnotu akcií podniku po prepuknutí krízy

Pri podnikovej kríze nedochádza len $\mathrm{k}$ strate dôvery $\mathrm{v}$ manažment podniku, ale dochádza najmä k strate dôvery zo strany verejnosti. Komunikácia v kríze je odkázaná na udržanie dôveryhodnosti podniku, prípadne jej opätovné získanie. To je možné prostredníctvom presvedčivej identifikácie top manažmentu s vhodnou komunikačnou úlohou, zrozumitel'nost'ou, priamočiarost'ou a otvorenost'ou. Komunikácia vo všeobecnosti a správne komunikačné opatrenia musia byt' posudzované ako centrálne komponenty krízového manažmentu. Efektívna interná, ako aj externá komunikácia ponúka mnohonásobné možnosti znižovania krízových dôsledkov a odstraňovania dôsledkov škôd na verejnosti. 


\section{2 Životný cyklus krízovej komunikácie}

Efektívna krízová komunikácia v podniku by mala byt's predstihom plánovaná a účelne riadená, nakol'ko každá kríza má svoj životný cyklus, ktorý je možné ovplyvnit'. V rámci životného cyklu krízy má svoj životný cyklus aj krízová komunikácia, ktorá sa takisto delí do troch fáz na:

- predkrízové opatrenia,

- opatrenia počas krízy,

- opatrenia po skončení krízy.

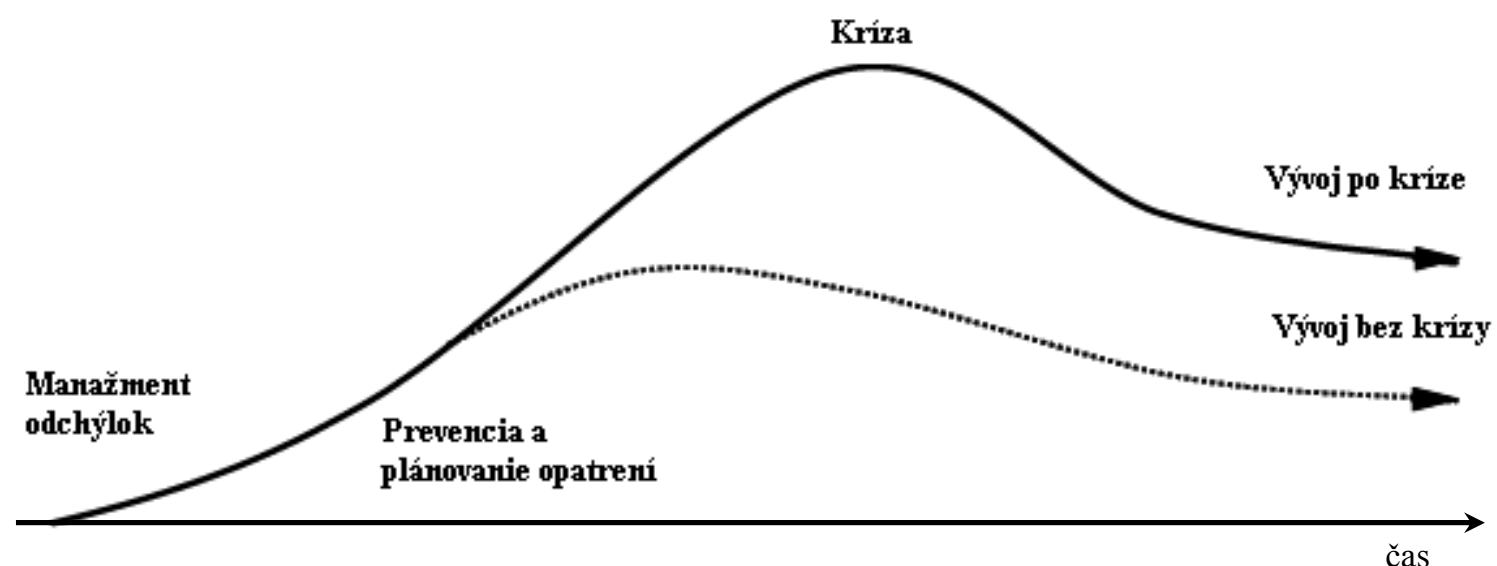

Obr. 3 Model pre manažment krízovej komunikácie

V období bez krízy sa manažment podniku zameriava na:

- manažment odchýlok, ktorý sa uplatňuje v bezkrízovom období a je zameraný na odhalenie potenciálnych rizík vzniku krízy v podniku,

- prevenciu vzniku hroziacej krízy a plánovanie opatrení na zabránenie, prípadne zmiernenie priebehu vznikajúcej krízy.

\subsection{Manažment odchýlok}

Hlavným znakom opatrení, ktoré vyplývajú z krokov manažment odchýlok, je ich proaktivita. Úlohou manažmentu $\mathrm{v}$ tomto kroku je permanentne analyzovat' interné a externé faktory, ktoré by mohli v budúcnosti pôsobit' t'ažkostí podniku. Predmetom hodnotenia sú aktuálne trendy vývoja faktorov a na základe ich vývoja sa identifikujú možné riziká pre podnik. Časový náskok, ktorý podnik analýzou faktorov získava, umožňuje manažmentu podniku definovat' adekvátne komunikačné stratégie a riešenia možných problémov skôr, ako vôbec vzniknú, poprípade umožňuje sa pripravit' a skrátit' čas riešenia problémov v čase, ked' vzniknú. Efektívne riadenie odchýlok vo vývoji analyzovaných faktorov, ktoré by mohli spôsobit' krízu podniku, umožňuje s vysokou pravdepodobnost'ou kríze včas predíst', a tak sa vyhnút' použitiu krízového plánu a zavedeniu krízovej komunikácie. 


\subsection{Prevencia a plánovanie opatrení}

Prevencia vzniku podnikovej krízy je zameraná na monitorovanie a vyhodnocovanie interných a externých faktorov, ktoré priamo ohrozujú podnik. Dochádza k identifikácii potenciálnych rizík, z nich hroziacich t’ažkostí pre podnik, ako aj k odvodeniu efektívnych opatrení, ktoré by mali redukovat' negatívne dôsledky eventuálnej krízy. Pre tento účel sa zostavuje krízový plán, prostredníctvom ktorého by bolo možné pozitívne ovplyvňovat' d'alší priebeh problémov v podniku.

Ak podnik priamo očakáva krízu, dochádza $\mathrm{k}$ zintenzívneniu získavania informácií o vývoji rizikových faktorov a monitorujú sa podnikové systémy včasného varovania, aby bolo možné dôkladne analyzovat' d'alší priebeh krízy. Pripravujú sa konkrétne opatrenia pre krízový priebeh, aby bolo možné čo najskôr a adekvátne reagovat' na nastupujúcu krízu. Definujú sa potenciálni členovia krízového tímu a určí sa interný mediálny hovorca. Okrem toho musia byt' $v$ tejto fáze definované interné komunikačné toky a detailný komunikačný plán s určením obsahu, časového priebehu a konkrétnymi adresátmi informácií.

Manažment musí v tejto fáze opakovane odhadovat' rozsah možných škôd v prípade vzniku krízy, ako aj určit' stupeň kontroly, ktorý je nutný pre podnik počas krízy. Ak sú potrebné opatrenia vo fáze prevencie a plánovania opatrení pre možný vznik krízy efektívne vypracované manažmentom podniku, dochádza $\mathrm{k}$ redukcii negatívnych dôsledkov pre podnik $\mathrm{v}$ čase nástupu a v priebehu krízy.

\subsection{Krízové opatrenia}

Ak sa podnik dostane do krízy, často používa menej proaktívne opatrenia. Manažment podniku sa snaží reagovat' na vzniknutú krízu vhodnými núdzovými opatreniami, aby došlo $\mathrm{k}$ redukcii strát vo vzt'ahu $\mathrm{k}$ verejnosti. Takéto reaktívne komunikačné aktivity majú obmedzenú efektívnost', pretože verejnost' vníma krízu subjektívne.

Vo fáze krízy je pre podnik dôležité, aby bol uplatňovaný krízový plán, ktorý bol zostavený vo fáze plánovania opatrení pre prípad vzniku krízy. Na realizácii krízového plánu sa podiel'ajú členovia krízového tímu. S externými médiami a verejnost'ou by mal komunikovat' jeden kompetentný mediálny hovorca. Externé médiá musia byt' včasne a pravidelne informované o aktuálnom vývoji v podniku.

V priebehu krízy musia byt' vypracované efektívne komunikačné opatrenia, ktoré poukazujú na konkrétne aktivity smerujúce k ovládnutiu krízy. Je potrebné ubezpečit' o sociálnej zodpovednosti podniku. Krízový manažér musí zabezpečit' pokračovanie činnosti podniku.

\subsection{Opatrenia po kríze}

Po prekonaní krízy v podniku nedochádza k ukončeniu komunikácie v podniku ani vo vzt'ahu k verejnosti. Vývoj v podniku musí byt' nad’alej monitorovaný, aby bolo možné včas reagovat' na možné riziká v vznikajúce t’ažkosti v momente ich vzniku. Intenzita krízy, škody, ktoré podnik utrpel počas krízy, ako aj dížka trvania krízy sú dôležitými faktormi, ktoré ovplyvňujú vnímanie krízy, tak v podniku, ako aj verejnost'ou. V tejto fáze je dôležité, aby podniky aj nad'alej venovali pozornost' verejnosti a zabezpečili spravodajstvo pre externé médiá. Dlhodobý komunikačný plán by mal, na základe skúsenosti z práve skončenej krízy, $\mathrm{v}$ čo najväčšej miere redukovat' škody budúcich možných kríz, poprípade im vopred zabránit'. 


\section{Komunikačné nástroje v jednotlivých fázach krízovej komunikácie}

Ciel’om komunikácie $\mathrm{v}$ rámci krízového manažmentu je likvidácia, zmena alebo stabilizácia negatívnych vplyvov a tým odvrátenie, prípadne odstránenie rizík možnej krízy. Pre tieto účely sa využívajú rôzne komunikačné nástroje. Intenzita využívania komunikačných nástrojov sa líši v závislosti od efektívnosti $\mathrm{s}$ akou pôsobia $\mathrm{v}$ jednotlivých fázach životného cyklu krízy. Vhodnost' využitia jednotlivých komunikačných nástrojov v jednotlivých fázach podnikovej krízy je súhrne uvedená v nasledujúcej tabul'ke 1 .

Tab. 1 Význam komunikačných nástrojov v jednotlivých fázach krízovej komunikácie

\begin{tabular}{|c|c|c|c|c|}
\hline Nástroje Fázy & $\begin{array}{l}\text { Manažment } \\
\text { odchýlok }\end{array}$ & $\begin{array}{l}\text { Prevencia a } \\
\text { plánovanie } \\
\text { opatrení }\end{array}$ & $\begin{array}{c}\text { Krízové } \\
\text { opatrenia }\end{array}$ & $\begin{array}{c}\text { Opatrenia } \\
\text { po kríze }\end{array}$ \\
\hline $\begin{array}{l}\text { Interná } \\
\text { komunikácia }\end{array}$ & $\odot$ & $\odot \odot$ & $\odot \odot \odot$ & $\odot \odot$ \\
\hline Public relations & (); $;$ & (:) & $(-) ;()$ & (;) $\odot$ \\
\hline Reklama & (;) :) & (-) & - & (;) $;$ \\
\hline Internet & ;) & (;) ;) & (;) (;) & (:) \\
\hline
\end{tabular}

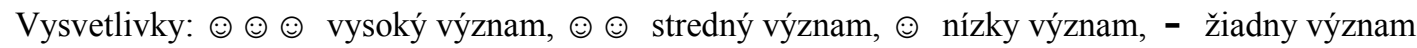

Zo všetkých uvedených komunikačných nástrojov majú najväčší význam interná komunikácia a Public relations. Reklama ako komunikačný nástroj je vhodná na dlhodobú stabilizáciu verejnosti vo vzt’ahu k podniku a to najmä v období pred a po kríze. Reklama je neúčinná v období podnikovej krízy. Vd’aka svojej rýchlosti získava internet rastúci význam najmä v období vzniku krízy a počas krízy.

\section{Záver}

Najvyšším ciel'om krízovej komunikácie je opatrné a pozitívne ovplyvňovanie verejnej mienky. Zodpovednost' za krízovú komunikáciu nesie manažment podniku. Jednotlivé opatrenia krízovej komunikácie uskutočňuje nielen manažment podniku, ale najmä mediálny hovorca po konzultácii s krízovým manažérom. Krízová komunikácia a činnost' mediálneho hovorcu by sa mali sústredit' na nástroje a možnosti klasickej mediálnej práce, pretože v prípade krízy sú použitel'né iba hodnoverné informácie.

\section{Literatúra}

1. EPSTEIN, M. J.: Communicating with Stakeholders in a Crisis. In: www.fei.org, 10/2003, s. 23-25.

2. JAHNÁTEK, L. - VIDOVÁ, J. - MIHOK, J.: Crisis Communications and Communication in Crisis. In: Acta Avionica, Košice 2007, roč. IX/2007 č. 13, s. 73-78. ISSN 1335-9479.

3. MIHOK, J. - VIDOVÁ, J.: Riadenie podniku v kríze. SjF TU v Košiciach, Košice 2006, s. 246. ISBN 80-8073-533-6. 
4. Strother, J. B.: Crisis Communication Put to the Test: The Case of Two Airlines on 9/11. In: IEEE Transactions on Professional Communication, 4/2004, s. 290-300.

5. VIDOVÁ, J.: Životný cyklus podnikovej krízy. In: 5. medzinárodná konferencia, Priemyslené inžinierstvo '07, Tu v Kočiciach, FEI, KEMaPI, Nový Smokovec, Vysoké Tatry, 2007, ISBN 978-80-8073-895-2, s. 209-218.

\section{Grantová podpora}

Príspevok bol pripravený $v$ rámci riešenia grantovej úlohy AV 4/0005/07: Využitie logistických sietí pri reštrukturalizácií podnikových procesov $\mathrm{v}$ malých a stredných priemyselných firmách. 